\title{
ОСОБЛИВОСТІ ФУНКЦІОНУВАННЯ МОРФОЛОГІЧНИХ РЯДІВ У ПОЕТИЧНИХ ТЕКСТАХ БЕЛЛИ АХМАДУЛІНОЇ Й ЛІНИ КОСТЕНКО
}

У статті схарактеризовано особливості функиіонування морфологосинтаксичних рядів у російськомовних і україномовних віршах на прикладі творчості Б. Ахмадуліної й Л. Костенко. Аналіз поетичного матеріалу дає підстави стверджувати, що Б. Ахмадуліна використовує гармонійні ряди нормативної довжини (три-чотирикомпонентні), щзо зближує ї художню систему із системами класичного типу. Л. Костенко регулярно використовує як ряди нормативної, так і ряди ненормативної і навіть надмаксимальної довжини, а також ланиюжки рядів, які взаємодіють, щзо дозволяє розглядати іï поетичний ідіостиль як художню систему вибіркового типу.

Ключові слова: поетичний текст, морфологічний (морфолого-синтаксичний) ряд, категоріальна селекція; ідіостиль; художня система; гармонійний тип, вибірковий тип.

Kozlov I. D., Kozlova A. H. Functional Specifics of Morphological Rows in Poetic Texts of Bella Akhmadulina and Lina Kostenko. The article describes some peculiarities of the functioning of morphological and syntactic rows in Russian and Ukrainian poems of B. Akhmadulina and L. Kostenko, the poets belonging to one generation. The object of the study was the corpus of poetic texts by the authors, the subject of research is the peculiarities of creation and functioning of grammatical rows in their poetry. The authors proceeded from the fact that the creation of rows of homogeneous grammemes is one of the most frequent results of morphological selection and that the formation of rows is one of poetic universals. Following O.O Skorobohatova and O.M. Holikova the authors understand a row in a broad sense (as a series of homogeneous members of sentences, appeals, nominative and infinitive sentences, and vertical rows, the formation of which is due to the poetic structure). On the basis of this approach, the works of B. Akhmadulina and L. Kostenko were analysed in order to study the rows of nouns, adjectives, adverbs, verb forms and other parts of the language and the use of homogeneous categorical rows. The analysis of peculiarities of formation of morphological rows on the basis of categorical selection and their functioning in the poetic texts of B. Akhmadulina and L. Kostenko allows to claim that B. Akhmadulina uses harmonious three-four-component rows (rows of standart length), remaining within the boundaries of the traditional poetic language. This brings her artistic system closer to classic type systems. L. Kostenko's work is characterized by the regular use of both standart and non-standart rows and even rows of super-maximal length (more than 7 components), as well as series 
of interacting rows. This allows to consider her poetic individual style as an artistic system of a selective type.

Key words: poetic text, morphological (morphological-syntactic) rows, categorical selection; individual style; artistic system; harmonic type, selective type.

\section{Вступ}

Поетична мова як мова віршованої поезії давно вже привертає увагу філологів, серед яких В.П. Григор'єв, С.Я. Єрмоленко, О.К. Жолковський, С.Т. Золян, Л.В. Зубова, І.О. Іонова, Ю.В. Казарін, І.І. Ковтунова, Ю.М. Лотман, А.К. Мойсієнко, О.Г. Ревзіна, В.З. Санников, О.О. Скоробогатова, Г.М. Сюта, Ю.М. Тинянов, Л.В. Щерба, Р.О. Якобсон та багато інших вітчизняних та зарубіжних вчених.

Серед актуальних аспектів вивчення поетичної мови окреме місце посідає дослідження способів створення виразності, зокрема актуалізація морфологічних значень і смислів, у тому числі в результаті селекції. Створення морфолого-синтаксичних рядів є одним 3 найбільш частотних результатів морфологічної селекції, бо саме за рахунок категоріального відбору відбувається формування рядів однорідних грамем. Ми розуміємо ряд у широкому лінгвопоетичному сенсі та розглядаємо і ряди однорідних членів речення, звертань, номінативних та інфінітивних речень, і вертикальні ряди, формування яких зумовлене віршовою структурою поетичного тексту. Таке розуміння ряду запропоноване М.Л. Гаспаровим і актуалізоване в роботах деяких вітчизняних мовознавців, зокрема О.О. Скоробогатової (Скоробогатова, 2012) та О.М. Голікової (Голікова, 2011).

Метою нашої статі є характеристика особливостей функціонування морфолого-синтаксичних рядів у російськомовних і україномовних віршах на прикладі творчості Б. Ахмадуліноїі Л. Костенко - поетес, які належать до одного покоління. Об’єктом дослідження слугує корпус поетичних текстів зазначених авторів, предметом - особливості створення та функціонування граматичних рядів у їхніх поезіях.

\section{Методи дослідження}

Як основний у дослідженні застосовано типологічний порівняльний метод, який дозволив, виходячи із зіставлення особливостей поетичної морфології авторських ідіостилів, класифікувати їх за різними типами. Використання інтерпретаційно-текстового методу спрямоване на характеристику морфологічних способів реалізації 
авторської інтенції щодо створення поетичних смислів. Елементи функціонального та лінгво-контекстуального методів використовувалися для характеристики поетичного потенціалу мовних одиниць у художньо-естетичному функціонуванні та місця граматичної моделі в поетичному контексті.

\section{Результати та дискусії}

Формування морфологічних рядів є поетичною універсалією. Фіксуються частиномовні ряди дієслівних форм, прикметників, прислівників та інших морфологічних одиниць і вживання однорідних категоріальних рядів. Як регулярні, зазвичай використовуються тричотирикомпонентні ряди. Вони наявні у творчості майже всіх поетів XIX-XXI сторіч, у тому числі в аналізованих ідіостилях: Они исполнили тяжёлую повинность / подснежников, отчаянья и писем (Б. Ахмадуліна «Пятнадцать мальчиков») (тут і далі цитуємо за: Ахмадуліна, 2012); ...гостья, умнииа, искусствовед... (Б. Ахмадуліна «Плохая весна»); И вот тогда - из слёз, из темноты, / из бедного невежества былого / друзей моих прекрасные черты / появятся и растворятся сно$в a$ (Б. Ахмадуліна «По улице моей который год...»); ...Столько раз / я знала здесь печаль и гордость / и нежную шагов нетвёрдость, / и нежную незрячесть глаз (Б. Ахмадуліна «Сон»); А хтось по ній прокопував рови. / Топтав, ганьбив нам поле найдорожче (Л. Костенко «Біль єдиної зброї») (тут і далі цитуємо за: Костенко Л. Збірка віршів. URL: https://www.e-reading.club/book.php?book=1000257); Самовитий - несамовитий - / не Сезанн - не Гоген - не Мане... (Л. Костенко «Ван-Гог»); Затінок, сутінок, день золотий (Л. Костенко «Затінок, сутінок, день золотий...»); ...mоді із ночі, з пітьми, з порожнечі... (Л. Костенко «Коли вже люди обляглися спати...») та ін.

Частиномовна подібність нерідко посилюється внутрішньокатегоріальною (наприклад, подібністю за числом i/або родом, особою i/ або часом (для дієслів)): Оно красою роз возросших / nuтает слух, $u$ нюх, и взгляд (Б. Ахмадуліна «Сад»); ...вибігали діти надвір. // Tonтали бузковий верес, / трусили на голови хвош. / Здіймали страшенний вереск, / ласкаво просили дощ:... (Л. Костенко «Дощі»).

У багатьох випадках ряди не лише морфологічно однакові, але й синтаксично однорідні. Наприклад: Пусть женщина, капризниия, мотовка, / тебя целует и грозит тебе! (Б. Ахмадуліна «Павлу 
Антокольскому. І»). Серед іменникових рядів, крім апелятивних, фіксуємо й утворювані онімами, зокрема антропонімами: Отныне будешь, славный муж и воин, / там, где Лаура, Беатриче, Керн (Б. Ахмадуліна «Теперь о тех, чьи детские портреты...»); Там Пастернак, а там живе Чуковський, / а там живе Довженко, там Хікмет (Л. Костенко «Підмосковний етюд»); ...Вернигора, Вернивода й Вернидуб - / три велетні - зібралися та й журяться (Л. Костенко «У чистім полі, в полі на роздоллі...»).

Збіг меж граматичного і віршового ряду сприяє змістовому та інтонаційному його виділенню. Наприклад: И широк дивный выбор всевышних щедрот: / ямб, хорей, амфибрахий, анапест и дактиль (Б. Ахмадуліна «Зимняя замкнутость»); - як у вас? - / - робота літо - спека - спрага - / - а настрій? - ... (Л. Костенко «Пінг-понг»); Я кину все. Я вірю в кілометри - / обвітрені, задихані і злі (Л. Костенко «Я кину все. Я вірю в кілометри...»), інколи й змістовому зближенню компонентів: Здається, з нами щось уже не те... / I навіть люди, місто й камні, / Щось прочепоче... (Л. Костенко «Здається, з нами щось уже не те...»), Така свавільна, вільна, молода - / невже $і$ я іду вже, як за плугом?! (Л. Костенко «І засміялась провесінь: - Пора!.»).

Віршова структура, наприклад, локалізація в різних віршових рядах, дозволяє виділяти в однорідному ряду змістові блоки: Різні бувають естафети. / Мімани міщанам передають буфети, / Заяложені ложки, тупі ножі, / Глупоту свою і думки чужі (Л. Костенко «Естафети»). У цьому випадку п’ятикомпонентний ряд однорідних членів поділяється на два блоки, кожен з яких створює змістову єдність. Блокування відбувається за рахунок дії закону про єдність та щільність віршового ряду. Свідоме включення до ряду явно «чужорідного» компонента сприяє створенню комічного, іронічного ефекту: Пророки, ангели, святі, / секретарки і херувими (Л. Костенко «Сьоме небо»). Винесення одного з компонентів в окремий віршовий ряд дозволяє виокремити його із загалу та виділити за змістом: И мокли волосы $\mathrm{Me-}$ деи, / Вплетаясь утром в водопад, / И капли сохли, и мелели, / И загорались невпопад (Б. Ахмадуліна «Грузинских женщин имена»); Зорі мають гіпнотичну силу. / Люди зіркою з давнини / називають жінку вродливу, / яхти, квіти й ордени (Л. Костенко «Зорі»); Ти звикла коні, гаківниці, стріли, / Зрадецькі хани з профілем шулік... (Л. Костенко «Скіфська баба»); А треба ж було думати, / иарі, Дантеси, 
Дубельти, / Ідалія Полетика, і всі на одну масть! (Л. Костенко «Віяло мадам Полетики»). В останньому прикладі компонент в окремому віршовому ряді виділяється ще й граматичними характеристиками: іменники царі, Дантеси, Дубельти мають чоловічий рід та вживаються у формі множини, що сприяє тому, що вони набувають додаткової семантики узагальнення. I тільки антропонім жіночого роду Ідалія Полетика, уживаний в однині, називає конкретну особу. Водночас використання займенника всі немов знімає це протиставлення, нагадуючи читачеві про активну роль «Мадам Інтриги» серед світських ворогів і гонителів О.С. Пушкіна.

Часто окремо локалізований елемент ускладнюється узгодженим або неузгодженим означенням: Сорочки в иеллофане, / Тарелки, кружева! (Б. Ахмадуліна «Невеста»); Номенклатурні дурні, бюрократи, / пласкі мурмила в квадратурі рам! (Л. Костенко «Червоні краплі глоду»); <...> Такої дивної отрути / я ще ніколи не пила. / Такої чистої печалі, / Такої спраглої жаги, / Такого зойку у мовчанні, / Такого сяйва навкруги. / Такої зоряної тиші. / Такого безміру в добі!.. (Л. Костенко «І як тепер тебе забути?»).

Особливістю ідіостилю Л. Костенко, на наш погляд, є наявність морфолого-синтаксичних рядів з антитезою, яка створюється протиставленням одного з компонентів, що за структурою нагадує негативне порівняння. Наприклад: Тарас гранітний дивиться суворо: / - A ви гартуйте ваші голоси! / Не пустослів'ям, пишним та барвистим, / не скаргами, / не белькотом надій, / не криком, / не переспівом на місиі, / а заспівом в дорозі нелегкій (Л. Костенко «Кобзарю»). У цьому шестикомпонентному ряду останній компонент протиставлений іншим. Ряди з протиставленням формуються поетесою не тільки з іменників, але й з дієслів: Моя любове! Я перед тобою. / Бери мене в свої блаженні сни. / Лиш не зроби слухняною рабою, / не ошукай і крил не обітни! / Не допусти, щоб світ зійшовся клином, / і не присни, для чого я живу. / Даруй мені над шляхом тополиним / важкого сония древню булаву. / Не дай мені заплутатись в дрібнииях, / не розміняй на спотички доpiг... (Л. Костенко «Моя любове! Я перед тобою...»). У наведеному прикладі протиставлення формально виражене вживанням у ряду, який складається з дев'яти компонентів - дієслів у формі імператива (бери, не зроби, не ошукай, не обітни, не допусти, не присни, даруй, не дай, не розміняци), лише двох без частки не (бери і даруй). 
Для поезій Л. Костенко характерне вживання рядів (зокрема іменникових та дієслівних), які утворені повторенням того самого слова, що сприяє актуалізації його семантики: Воно мені світить і світить, / таке воно в світі одне. / - Я Світязь, я Світязь, я Світязь! <..> - Батурин, Батурин, Батурин! - / лунає мені навздогін. <..> - Я Альта, я Альта, я Альта! - / тонесенько плаче ріка... (Л. Костенко «Я хочу на озеро Світязь»); I тільки вітер, вітер, вітер... / I тільки сонце, сонце, сон... (Л. Костенко «Іма Сумак»); Ми велетні, ми велетні, ми велетні. / Ми телепні, ми телепні, ми телепні! / I сила ж є, і серие не мізерне, / і сто віків ні вмерти, ні заснути, - / все вернем, вернем, вернем, вернем! / А вже пора було й перевернути (Л. Костенко «У чистім полі, в полі на роздоллі...»). В останньому фрагменті спостерігаємо видове співположення: тричі використано дієслово недоконаного виду у теперішньому часі вернем, що підкреслює повторюваність дії, і одне дієслово доконаного виду у формі інфінітива - перевернути, уживання якого в цьому контексті вказує на марність зусиль, відсутність результату.

Ряд може бути представлений субстантивами в одній відмінково-числовій формі: Красива осінь вишиває клени / Червоним, жовтим, срібним, золотим. / А тистя просить: - Виший нас зеленим! / Ми ще побудем, ще не облетим (Л. Костенко «Красива осінь вишиває клени...») (форма орудного відмінка однини). Субстантивне значення 'колір' визначається контекстуально. Субстантиват чорним у давальному відмінку множини у другій строфі вірша корелює з рядом субстантиватів у першій завдяки граматичній омонімічності, бо є омоформою прикметника (і субстантивата) чорним (орудний відмінок однини): А листя просить: - Дай нам тої втіхи! / Сади прекрасні, роси - як вино. / Ворони п'ють надкльовані горіхи. / А щзо їм, чорним? Чорним все одно.

Дієслівний однорідний морфолого-синтаксичний ряд зазвичай представлений дієсловами в однаковій граматичній формі, із відповідністю за часом, особою і числом: Покорялись руки бедные, / обнимали сгоряча / и взвивались пальцы белье / у иьгана-скрипача (Б. Ахмадуліна «Старинный портрет»); Зайду у хату... озирнусв... притихну... / Час б’є копитом. Встигну, не біда. / Час б’є копитом. Я сказала - встигну! / Ось трохи відпочину - i гайда! (Л. Костенко «Летять на землю груші, як з рогаток...»); Tym як не ступиш, 
то не втрапиш. / Іщце цимбали й скрипку втратиш (Л. Костенко «Музики»).

У багатьох поезіях збігається й доконаність або недоконаність дієслів, що є елементами ряду. Але у віршах Л. Костенко ця закономірність неодноразово порушується: А то були якісь магічні пальці. / Вони німіли на якомусь «фа». / I прислухались... / I боялись фбальші. / Так, як боїться і моя строфа. / Вони вертались, мучились, питали. / Вони відклали славу на колись. / Вони ту фальш роздерли, розтоптали, / і аж збіліли, так вони сплелись (Л. Костенко «Коли вже люди обляглися спати...»). У цьому поетичному фрагменті не тільки використовуються і вертикальні, і горизонтальні дієслівні ряди, але вони упорядковуються дієсловами як недоконаного (були, німіли, прислухались, боялись, вертались, мучились, питали), так і доконаного виду (відклали, роздерли, розтоптали, збіліли, сплелись), що сприяє членуванню ряду. Блокування відбувається саме на підставі видової віднесеності Звертає на себе увагу довжина дієслівного ряду, його багатокомпонентність. Поєднання в граматичних рядах дієслів доконаного і недоконаного виду є однією з особливостей ідіостилю Л. Костенко.

Якщо для Б. Ахмадуліної характерні гармонійні три-чотирикомпонентні ряди, то в Л. Костенко знаходимо як ряди нормативної, так і ряди ненормативної (5, 6, 7 компонентів) и навіть надмаксимальної довжини (понад 7 компонентів), а також ланцюжки рядів. Нерідко в багаточленних рядах використовується прийом блокування компонентів, що полегшує сприйняття ряду.

Дієслівний ряд може бути представлений формою інфінітива: Отрадой - умертвить? Иль умереть? / Или корыстно почернеть от рабства? (Б. Ахмадуліна «Варфоломеевская ночь»), 2012: 95); ... ведь никогда им так не пахнуть, / как это делают сады. // Им на губах не оставаться, / им не раскачивать шмеля, / им никогда не догадаться, / что значит мокрая земля (Б. Ахмадуліна «Цветы»); А наші мрії як кіно... / Пройдуть, загаснуть і затихнуть / У каламбурі почуттів... (Л. Костенко «Гротеск»); Сполохать ніч дзвінкими голосами, / зайти у нетрі, збитися - аж ні! (Л. Костенко «Підмосковний етюд»). Інфінітивні ряди виразні й семантично значущі, що пов'язано 3 особливим статусом цієї форми (ії дієслівно-іменною семантикою (Виноградов, 1986), прегнантністю (Голікова, 2011), поетичною 
прецедентністю (Жолковський, 2000; Жолковський, 2004; Голікова, 2007; Голікова, 2011). Ряд, що утворений повторюваним інфінітивом, який позбавлений категоріальних значень часу, числа і способу, підкреслює кореневу семантику, прегнантність форми, розширює змістовий ореол слова.

У досліджуваних ідіостилях створюються також прислівникові ряди - вертикальні: Но как же всё напрасно, / но как же всё нелепо! / Тебе идти направо. / Мне идти налево (Б. Ахмадуліна «Я думала, что ты мой враг...»); ...nерекидом, / колесом, / вистрибом / вибігали діти надвір... (Л. Костенко. «Дощі») і горизонтальні: Мені нестерпно, душно, передгрозно (Л. Костенко «Такий чужий і раптом - неминучий...»), зокрема й такі, що передають значення часу: Люблю чернігівську дорогу - / весною, влітку, восени ('завжди', 'у будь-яку пору року') (Л. Костенко. «Люблю чернігівську дорогу...»); Умер проїздом. Корсунь спав, байдужий, / що десь свогодні, вчора чи торік / умер проїздо, сивий і недужий, / якийсь старий самотній чоловік ('будь-коли', 'не має значення, коли') (Л. Костенко «Пам'ятник I.M. Солошенку»).

У деяких випадках один з компонентів ряду (у наступному прикладі останній) має семантику узагальнення: ...я залишуся в сериі твоєму / на свогодні, назавтра, навік. / І минатиме час, нанизавши / сотні вражень, імен і краӥн, - / на свогодні, на завтра, назавжди! - / ти залишишся в сериі моїм. <...> То все разом, а ти - окремо. / I свогодні, $\boldsymbol{i}$ завтра, й навік (Л. Костенко «Розкажу тобі думку таємну...»). I це характерно не лише для прислівникових рядів: Десь там брязкіт і скреготіння, залізничний / постійний шум... (Л. Костенко «Лист»); Ви - мій щоденний, звичний мій тренаж, / мої гантелі, турніки і штанги (Л. Костенко «Коректна ода ворогам»); Іили музики із весілля. / Цимбали, бубон і скрипаль (Л. Костенко «Музики»). У першому прикладі іменник шум набуває семантики узагальнення, проте інші два компоненти ряду - брязкіт і скреготіння - виконують функцію уточнення, називаючи характер шуму. Аналогічним чином побудований іменниковий ряд у двох інших поетичних фрагментах, де носіями семантики узагальнення є іменники тренаж (у другому прикладі) та музики (у третьому прикладі), а інші елементи ряду гантелі, турніки і штанги та иимбали, бубон і скрипаль - лише конкретизують, відповідно, характер «тренажу» (спортивне знаряддя) та музичну спеціалізацію кожного з музик, двоє з них поіменовані 
за метонімічним принципом - назвами музичних інструментів (иимбали і бубон) і тільки один відповідним іменником, що називає людину-музиканта за фахом - скрипаль.

Усередині іменного або дієслівного ряду іноді відзначаємо родову повноту. Поетичний зміст, що виникає в таких сполученнях, пов'язаний з ідеєю змістової повноти: Приветствуют во мне при встрече / Своё освобождение, нормальный сон и пищу... (сер. р, ч. р., ж. р.) (Б. Ахмадуліна «Пятнадцать мальчиков»); Две радуги, два неба, два огня (ж. р., сер. р, ч. р.), / бесстьцница, горят в твоих коленях (Б. Ахмадуліна «Мотороллер»). Окремі приклади створення родової повноти можна знайти й у Л. Костенко: Ця казка днів - вона була недовгою. / Цей світлий сон - пішов без вороття. / Це тихе сяйво над моєю долею! - / Воно тишилось на усе життя (ж. р, ч. р., сер. р.) (Л. Костенко «Я дуже тяжко Вами відболіла...»); Туm съоме небо, / верх бажань, / мета духовної жадоби, / причина слізних уповань... (сер. р., ч. р., ж. р., ж. р.) (Л. Костенко «Сьоме небо»).

Таким чином, обидві поетеси продовжують класичну поетичну традицію передачі ідеї змістової повноти поєднанням у ряду іменників трьох родів (див. докладно: (Скоробогатова, 2015)). Водночас для Л. Костенко характерне використання в подібних випадках чотирикомпонентних рядів, у яких одна з форм роду повторюється.

Морфолого-синтаксичні ряди в поетичному тексті Ахмадуліної можуть формуватися за рахунок відбору абстрактних іменників. Наприклад: Войти? Как можно? Сколько раз / я знала здесь печаль и гордость, / и нежную шагов нетвёрдость, / и нежную незрячесть глаз (Б. Ахмадуліна «Сон»). Але в поезіях Ліни Костенко такі ряди не були виявлені. Припускаємо, що для ії ідіостилю вони не є характерними.

Інколи елементи ряду входять до складу різних предикативних одиниць, що притаманне вертикальним рядам, які досить часто зустрічаються у фігурах синтаксичного паралелізму. Наприклад: Плакали сині очі. / Плакали сірі очі. / Плакали чорні очі. / I всі - мої (Л. Костенко «Сходить сонце...»). В останньому прикладі наявний синтаксичний паралелізм з константними підметом (очі) і присудком (плакали) і змінним означенням-колоративом (сині-сірі-чорні). На тлі повтору іменника й дієслова прикметниковий ряд колоративів актуалізується. 
Нерідко в одному тексті наявні два та більше морфолого-синтаксичних ряди, інколи вони взаємодіють: Там, на землі, щось (1) падало, ивіло, / було (2) рожеве, синє і зелене (Л. Костенко «Астральний зойк») (у цьому прикладі поетеса використовує два трикомпонентні ряди).

\section{Висновки}

Відношення до прийому $є$ універсальною типологічною ознакою, яка, як уважають дослідники, дозволяє розділити усі віршовані тексти на дві категорії: «1) художні системи в и 6 і р к о в о г о типу; 2) художні системи к л а с и ч н о г о типу» (виділення автора; переклад з російської наш. - Є. К., А. К.) (Григорьев В.П. та ін., 1990: 83). «Художні системи класичного типу характеризуються гармонійним відношенням до прийому, проте в художніх системах вибіркового типу використовується “експлуатація прийому”, який багаторазово повторюється, виділяючись на загальному фоні» (Козлов, 2016 : 41).

Таким чином, аналіз особливостей формування на підставі категоріальної селекції морфологічних рядів ї̈х функціонування в поетичних текстах Б. Ахмадуліної і Л. Костенко дає підстави стверджувати, що Б. Ахмадуліна використовує гармонійні три-чотирикомпонентні ряди (ряди нормативної довжини), залишаючись у межах сформованої поетичної традиції, що зближує її художню систему з системами класичного типу. Для творчості Л. Костенко характерне регулярне використання як рядів нормативної, так і рядів ненормативної і навіть надмаксимальної довжини (понад 7 компонентів), а також ланцюжків рядів, що взаємодіють. Це дозволяє розглядати іії поетичний ідіостиль за означеним критерієм як художню систему вибіркового типу.

Перспективним, на наш погляд, $є$ дослідження морфологічних рядів в ідіостилях сучасних російських та українських поетів як ознаки не тільки індивідуально-авторських особливостей, але й загальних напрямів розвитку поетичної мови у різних локусах функціонування.

\section{ЛІТЕРАТУРА}

1. Ахмадулина Б. А. Собрание сочинений в одном томе. Москва: Изд-во «АЛЬФА-КНИГА», 2012. 856 с. (Полное собрание в одном томе). 2. Виноградов В. В. Русский язык (Грамматическое учение о слове): учеб. пособие для вузов / отв. ред. Г. А. Золотова. 3-е изд., испр. Москва: Высшая школа, 1986. 640 с. 3. Голікова О. М. Номінативні та інфінітивні ряди в художньому тексті: автореф. дис. ... канд. філол. наук: 10.02.02. Харків, 2011. 20 с. 4. Голикова О. Н. Языковые средства передачи «логики 
бесконечного небытия» в стихотворении Даниила Хармса. Русская филология. Украинский вестник: Республиканский научно-методический журнал. 2007. № 2-3 (33). С. 96-101. 5. Григорьев В. П., Ковтунова И. И., Ревзина О. Г. и др. Очерки истории языка русской поэзии XX века. Поэтический язык и идиостиль: Общие вопросы. Звуковая организация текста / под ред. В.П. Григорьева. Москва: Наука, 1990. 304 с. 6. Жолковский А. К. Бродский и инфинитивное письмо: материалы к теме. Новое литературное обозрение. 2000. № 45. С. 187-198. 7. Жолковский А. К. Инфинитивное письмо и анализ текста: «Леиклос» Бродского. Поэтика исканий, или Поиск поэтики: Материалы международной конференциифестиваля «Поэтический язык рубежа XX-XXI веков и современные литературные стратегии» (ИРЯ им. В. В. Виноградова РАН). Москва: Азбуковник, 2004. С. 132-150. 8. Козлов Є. Д. Поэтическая морфология идиостиля Б. Ахмадулиной и Ю. Мориц: дисс. ... канд. филол. наук: 10.02.02. Харьков, 2016. 9. Костенко Л. Збірка віршів. URL: https://www.e-reading.club/book. php?book=1000257. 10. Скоробогатова Е. А. Грамматические значения и поэтические смыслы: поэтический потенциал русской грамматики (морфологические категории и лексико-грамматические разряды имени): моногр. Харьков: НТМТ, 2012. 480 с. 11. Скоробогатова Е. А. Поэтический потенциал именных грамматических категорий (на материале русской поэзии XIX-XXI веков): дисс. ... доктора филол. наук: 10.02.02. Харьков, 2015.

\section{REFERENCES}

1. Akhmadulina, B. A. (2012). Sobranie sochinenij v odnom tome [Collected works issued in one volume]. Moscow: ALFA-KNIGA [in Russian]. 2. Vinogradov, V.V. (1986). Russkij yazyk (Grammaticheskoe uchenie o slove) [Russian language (Grammatical studies of word)]. Moscow: Vysshaya shkola [in Russian]. 3. Golikova, O. M. (2011). Nominatyvni ta infinityvni riady $\mathrm{v}$ khudozhnomu teksti [Nominative and infinitive rows in literary texts]. Extended abstract of candidate's thesis. Kharkiv [in Ukrainian]. 4. Golikova, O. M. (2007). Yazykovie sredstva peredachi "logiki beskonechnogo nebytiya" v stihotvorenii Daniila Kharmsa [Language means of conveying of "the logic of non-existence in Daniil Kharms poems]. Russkaya filologiya. Ukrainskij vestnik: Respublikanskij nauchno-metodicheskij zhurnal - Russian philology. Ukrainian Bulletin: Republican Scientific and Methodological Journal, 2-3 (33), 96-101 [in Russian]. 5. Grigorev, V. P. and others. (1990). Ocherki istorii yazyka russkoj poezii XX veka. Poeticheskij yazyk i idiostil. Obshie voprosy. Zvukovaya organizaciya teksta. [Studies of the history of the language of Russian poetry of XX century. Poetic language and individual style. General questions. Phonic organization of texts]. Moscow: Nauka [in Russian]. 6. Zholkovsky, A.K. (2000). Brodsky i infinitivnoe pismo: materialy k teme [Brodsky and infinitive writing: topic materials] Novoje literaturnoe obozrenie - New literary review, 45, 187-198 [in Russian]. 7. Zholkovsky, A. K. (2004). Infinitivnoe pismo i analiz teksta: «Leiklos» Brodskogo [Infinitive writing and text analysis: Brodsky «Leiklos»]. Poetika iskanij, ili Poisk poetiki - The poetics of pursuit or the pursuit of poetics: Materialy mezhdunaradnoj konferentsii-festivalya "Poeticheskij yazyk rubezha $X X-X X I$ vekov i sovremennye literaturnye strategii» - Proceedings from the international festival «Poetic language of the turn of XX and XXI centuries and modern literary stratagies» (pp. 132-150). Moscow: Azbukovnik [in Russian]. 8. Kozlov, I. D. (2016). Poeticheskaya morfologiya idiostilya B. Akhmadulinoj i J. Moritz [Poetic morphology of B. Akhmadulina and J. Moritz invividual 
style]. Candidate's thesis. Kharkiv [in Russian]. 9. Kostenko, L. Zbirka virshiv [Book of poems]. Retrieved from https://www.e-reading.club/book.php?book=1000257 [in Ukrainian]. 10. Skorobogatova, E. A. (2012). Grammaticheskie znacheniya i poeticheskie smysly: poeticheskij potencial russkoj grammatiki (morfologicheskie kategorii I leksiko-grammaticheskie razryady imen) [Grammatical meanings and poetic sense. Poetic potential of Russian grammar (morphological categories and lexico-grammatical classes of nouns)]. Kharkiv: HTMT [in Russian]. 11. Skorobogatova, E. A. (2015). Poeticheskij potencial imennyh grammaticheskih kategorij (na materiale russkoj poezii XIX-XXI vekov) [Poetic potential of grammatical categories of noun (case study of Russian poetry of XIX-XXI centuries)]. Doctor's thesis. Kharkiv [in Russian].

Козлов Євген Дмитрович - кандидат філологічних наук, доцент кафедри ділової іноземної мови та перекладу, Національний технічний університет «Харківський політехнічний інститут». Вул. Кирпичова, 2, м. Харків, 61000, Україна.

Tel.: +38-096-961-83-45

E-mail: boji@meta.ua

ORCID: 0000-0003-3364-856X

Kozlov Yevhen Dmytrovych - Ph.D in Philology, Associate Professor, Department of Business Foreign Language and Translation, National Technical University "Kharkiv Polytechnic Institute”. Kyrpychov Str., 2, Kharkiv, 61000, Ukraine.

Козлова Алла Григорівна - кандидат філологічних наук, доцент, доцент кафедри світової літератури, Харківський національний педагогічний університет імені Г. С. Сковороди. Вул. Валентинівська, 2. м. Харків, 61168, Україна.

Tel.: +38-050-918-85-60

E-mail: kozlovaag7@gmail.com

ORCID: 0000-0002-2177-7746

Kozlova Alla Hryhorivna - Ph.D in Philology, Associate Professor, Department of the World Literature, H.S. Skovoroda Kharkiv National Pedagogical University. Valentynivska Str., 2, Kharkiv, 61168, Ukraine. 